\title{
A Survey of Fish Fauna Distribution and Abundance in Gwaigwaye Reservoir Katsina State, Nigeria
}

\author{
*11 AWAL, N; ${ }^{2}$ NAFIU, MI; \\ ${ }^{*}$ Department of Biology, Ahmadu Bello University, Zaria, Nigeria \\ ${ }^{2}$ Department of Biological Sciences, Federal University, Gusau, Nigeria \\ *Corresponding Author Email: lnura@abu.edu.ng; lawalnura96@gmail.com; Tel: 08068163723
}

\begin{abstract}
The study on a survey of fish fauna distributions and abundance in gwaigwaye reservoir, katsina state was carried out from May 2013 to April 2014 to establish physical, chemical, and biological parameters (fish) of Gwaigwaye reservoir. Four sampling stations were selected. Some physico-chemical parameters were also determine to assess the level of pollution of the reservoir using standard methods and procedures which were correlated with the different fish species to determine fish abundance and distributions. Analysis of variance indicates no significant difference in fish fauna distribution and abundance among the four stations $(\mathrm{P}>0.05)$. The result indicated Fish fauna percentage composition were Tilapia zilli (17.32\%), Clarias gariepinus (16.17\%), Oreochromis niloticus (15.27\%), Lates niloticus (13.80\%), Bagrus. bayad (12.91\%), Momyrus senegalensis (9.90\%), Labeo senegalensis (7.41\%) and Synodontis clarias $(7.28 \%)$.
\end{abstract}

DOI: https://dx.doi.org/10.4314/jasem.v24i12.27

Copyright: Copyright (C) 2020 Lawal and Nafiu. This is an open access article distributed under the Creative Commons Attribution License (CCL), which permits unrestricted use, distribution, and reproduction in any medium, provided the original work is properly cited.

Dates: Received: 11 October 2020; Revised: 22 November 2020; Accepted: 15 December 2020

Key words: Fish; Survey; Distribution; Abundance; Gwaigwaye reservoir.

It is well established that the productivity of a reservoir depends on its ecological conditions and by monitoring the water quality; productivity can be increased to obtain maximum sustainable yield of fish (Mustapha, 2011). Maintenance of healthy aquatic environment and production of sufficient food in reservoir are primarily linked with successful reservoir culture operations. Various studies had been conducted on changes brought about by biotic and abiotic factors of river as a result of damming. However, responses of rivers and its ecosystem to damming are complex and varied as they depend on local sediment supplies, geomorphic constraint, climate, dam structure and operation (Offem and Ikpi, 2011). Life in aquatic environment is largely governed by physico-chemical characteristics and their stability. These characteristics have enabled biota to develop many adaptations that improve sustained productivity and regulate its metabolism (Olele and Ekelemu, 2008). Many of these reservoirs were built as a result of societal demand for drinking and industrial water supplies, irrigation, hydroelectric power generation, fish production and recreation. With time however, most of these reservoirs have secondary functions such as navigation, industrial processing, flood protection, urban run-off control and tourism super imposed on them (Mustapha, 2011). Impacted changes in the water quality are reflected in the biotic community structure, with the most vulnerable deing, while the most sensitive species act as indicators of pollution. In Africa, there are many shallow reservoirs, but their numbers are still few considering their functions, population demand for their resources and their roles. In order for these reservoirs to perform the purpose(s) of their establishment as well as other functions that might be super imposed on them, plankton community structure and composition of these reservoirs should be well known; this will provide a valuable insight to its effective management (Mustapha, 2011). Out of the $29,966,920$ tonnes of aquatic organisms produced by freshwater aquaculture in 2005, fishes represented $96 \%$ of the total, whereas crustaceans, molluscs, amphibians and all other animals combined only represented the remainder $4 \%$, with $1,308,547$ tonnes (FAO, 2008). Nigeria is blessed with about 853,600 hectares of freshwater capable of producing over 1.5 million metric tonnes of fish annually (FAO, 2009). Because of this there is need to exploit means of using these precious resources, even though there are some hindrances, which includes effects of domestic and agricultural wastes on the water quality and aquatic life, physical and chemical factors like temperature, turbidity, $\mathrm{pH}$, dissolved gases $\left(\mathrm{O}_{2}\right.$ and $\left.\mathrm{CO}_{2}\right)$, salts and nutrients. It is no doubt; reservoirs have contributed to 
the economic growth of many nations, Nigeria inclusive (Watson, 2000). Freshwater fishes are in decline worldwide because of human caused degradation of aquatic habitats (Dudgeon et al., 2006; Geist 2011; Helfman, 2007). Anthropogenic climate change is further accelerating declines of many freshwater fish species, particularly in regions with arid or Mediterranean climates (Aparicio et al., 2000; Moyle et al., 2011; Moyle et al., 2012). However, the migration of large numbers of people increase the level of human activities in the water shed and intensifies human pressures upon the reservoir. Gwaigwaye Reservoir is a man-made lake that serves as a source of water supply for domestic uses to the surrounding communities, as such knowledge of it's fish fauna is of immense importance in assessing its productivity and to provide better understanding of the reservoir ecosystem. This paper aim to determine a survey of fish fauna distribution and abundance in gwaigwaye reservoir, katsina state. The objectives of this paper are to determine the monthly abundance and percentage of fish landing in gwaigwaye reservoir and also to determine the relationship between fish fauna distribution and variation in physico-chemical parameters of gwaigwaye reservoir.

\section{MATERIALS AND METHODS}

Sampling Procedures: Four sampling stations were selected based on stratified method of sampling in Gwaigwaye reservoir. Station I was located at the upstream, station II was located at middle area towards east, Station III was located at middle area towards west while Station IV was located at downstream (water spill way). The distance between stations was $20 \mathrm{~m}$ apart. The procedural plan of this study was monthly sampling of water and Fish from May 2013 to April 2014. The water was sampled at the surface level by dipping four of the one litre plastic sampling bottle containing $2 \mathrm{ml}$ of $\mathrm{KMNO}_{4}$ in each of the four sites for Biological Oxygen Demand (BOD) and Dissolve Oxygen (DO) together with another four of the five litre bottles by sliding them over the upper surface of water with their mouth open against the water current to permit undisturbed passage of the water into the bottle, it was then transported to hydrobiology laboratory for analysis of physicochemical parameters to determine the suitability of the water for fish survival.

The fish species were caught at each sampling sites (comprising of sampling A, B, C and D). At the sampling sites, the total numbers of fish were based on months (from June to May 2013/2014) and were recorded as percentage abundance. The fish species collected from the sampling sites were also obtained based on the type of fish species and were recorded based on their relative abundance which was expressed below:

$$
\frac{X}{Y} x 100
$$

Where $X=$ number of fish species collected in each month; $\mathrm{Y}=$ total number of fish species collected in each month.

The family relative abundance of the fish species caught was also recorded as follows: (1) BagaridaeBagrus bajad; (2) Cichlidae- Tilapia zilli and Oreochromis niloticus; (3) Cyprinidae- Labeo senegalensis; (4) Mormyridae- Mormyrus senegalensis; (5) Machokidae- Synodentis clarias; (6) Latidae- Lates niloticus and (7) Claridae- Clarias gariepinus

The fish samples were collected in an ice pack container from the fish landing sites based on previous arrangements with the fishermen. 10\% formalin was used for sample preservation before been transported to fishery laboratory where the fish identification to species level was performed with the aid of reference materials such as Balogun (2006), Idodo-umeh (2003), Babatunde and Raji, (2004), and Pauly et al. (2004).

Identification of Fish Species: Fish samples were collected with ice pack containers labelled A, B, C and $\mathrm{D}$ respectively from the fish landing sites. Fishes were identified using standard reference materials such as Balogun (2006); Idodo-umeh (2003), and Pauly et al. (2004).

Data Analyses: Analysis of variance (ANOVA) was performed to test the level significance at $\mathrm{P}<0.05$ on the fish species. Duncan's Multiple Range Tests (DMRT) was used to separate means. Pearson's correlation coefficient was used on the data to determine significant relationships between the fish fauna and physico-chemical parameters.

\section{RESULTS AND DISCUSSION}

The results of the analysis carried out on the water and fish samples collected from gwaigwaye reservoir showed variations in the fish species based on distribution and abundance of the fish species present in the reservoir.

Fish Fauna: The total number of fishes identified in the four stations during the period of the study was 1565; which are Bagrus bajad, Tilapia zilli, Clarias gariepinus, Momyrus senegalensis, Oreochromis 
niloticus, Synodontis clarias, Labeo senegalensis, Lates niloticus (Table 1)

Tilapia zilli: Correlation revealed there was a positive correlation with D.O, $\mathrm{Cl}^{-}, \mathrm{PO}_{4}, \mathrm{NO}_{4}, \quad \mathrm{SO}_{4}$, Temperature, BOD, Calcium and Alkalinity and negative correlation with $\mathrm{pH}$, Conductivity, Total Dissolve Solids (Table 2). The percentage composition of fishes (Table 1) indicated Tilapia zilli has the highest percentage with $17.32 \%$, abundance composition. The highest number was recorded in the month of August while the lowest was recorded in the month of October and November was the least.

Clarias gariepinus: Correlation revealed there was a positive correlation with chloride and hardness and negative correlation with $\mathrm{pH}$, Conductivity, total dissolve solids (Table 2). The percentage composition of fishes (Table 1) indicated Clarias gariepinus has the second highest population which accounted for the $16.17 \%$ of the total number of fishes count identified during the period of the study; the highest number was recorded in the month of August while the lowest count was recorded in the month of April.

Oreochromis niloticus: Correlation revealed there was a weak positive correlation with the other physicochemical parameters and negative correlation with $\mathrm{pH}$, Electrical conductivity, total dissolve solids (Table 2). The percentage composition of fishes (Table 1) indicated the total number of Oreochromis niloticus identified was 238 which account for $15.27 \%$ of the total fishes identified, there was monthly variation of Oreochromis niloticus recorded during the period of study; the highest number was recorded in the month of april and June while the lowest was in February.

Lates niloticus: Correlation revealed there was a weak positive correlation with $\mathrm{DO}, \mathrm{Cl}^{-}, \mathrm{TDS}, \mathrm{PO}_{4}$, Hardness, $\mathrm{NO}_{4}, \mathrm{SO}_{4}$, Temperature, $\mathrm{EC}$, and negative correlation with Biochemical Oxygen and $\mathrm{pH}$ (Table 2). The percentage composition of fishes (Table 1) indicated the total number of Lates niloticus identified during the period of the study was 216 , which accounted for the $13.80 \%$ of the total identified and recorded fishes during the period of the study. The highest count was recorded in wet season (i.e September) and the lowest in dry season (i.e April).

Bagrus bayad: Correlation revealed there was a positive correlation with Chloride, Sulphide and Hardness while negative correlation with $\mathrm{pH}$, Conductivity and Total dissolve solids (Table 2). The percentage composition of fishes (Table 1) indicated the total number of Bagrus bajad identified during the period of the study was 202, which accounted for the
$12.91 \%$ of the total identified and recorded fishes during the period of the study. The highest record was in July of wet season and the lowest in January, March and May of dry season.

Mormyrus senegalensis: Correlation revealed there was a positive correlation with Chloride, Sulphide and Hardness while negative correlation with $\mathrm{pH}$, Conductivity and Total dissolve solids, Biochemical Oxygen Demand and Calcium (Table 2). The percentage composition of fishes (Table: 1 ) indicated the total number of

Mormyrus senegalensis identified during the period of the study was 155 , which accounted for the $9.90 \%$ of the total identified and recorded fishes during the period of the study. The highest record was in June wet season and the lowest in March of dry season.

Labeo senegalensis: Correlation revealed there was a positive correlation with Chloride, Sulphide and Alkalinity while negative correlation with dissolve oxygen, conductivity, calcium and total dissolve solids (Table 2). The percentage composition of fishes (Table: 1) indicated the total number of Labeo senegalensis identified during the period of the study was 116 , which accounted for the $7.41 \%$ of the total identified and recorded fishes during the period of the study. The highest record was in October and February while the lowest in January and April.

Synodontis clarias: Correlation revealed there was a weak positive correlation with other physico-chemical parameters while negative correlation with $\mathrm{pH}$, Conductivity, Calcium and Total dissolve solids (Table 2). The percentage composition of fishes (Table:1) indicated the total number of Synodontis clarias identified during the period of the study was 114 , which accounted for the $7.28 \%$ of the total identified and recorded fishes during the period of the study. The highest record was in June wet season and the lowest in October dry season.

Fish Fauna Distribution and Abundance: Fish fauna composition in Gwaigwaye reservoir was dominated by Tilapia zilli, and then Clarias gariepinus, which were followed by Oreochromis niloticus and Lates niloticus, Bagrus bajad, Momyrus senegalensis, Synodontis clarias and Labeo senegalensis. The fish fauna composition and abundance varies with months and seasons, which may be due to fluctuation of physicochemical parameters and reduction in abundance of phytoplanktons, which are the primary producers. Mahar (2003) reported factors such as light intensity; food availability, dissolved oxygen, and predation affect the population composition of 
zooplankton including fish fauna (Table 2). Gwaigwaye reservoir had higher fish fauna composition and abundance during the rainy season which could be due to land use around riverine areas in Nigeria which is predominantly for farming (Adeyemi et al., 2009); this could be a possible explanation for the high levels of $\mathrm{PO}_{4}{ }^{-} \mathrm{P}$ that may result from run-offs during rainy season as observed in this study. This observation coincides with that of Edward and Ugwumba (2010) in which they reported the increased number of zooplankton including fish fauna during the rainy season that was linked to the influx of nutrient. All the fish fauna and phytoplankton indicated high productivity in the rainy season and decrease to dry season, the mean values of 0.21 for $\mathrm{NO}_{3}{ }^{-} \mathrm{N}$ were also found to be above expected concentration range of natural unpolluted waters of 0.1 mg/l (UNESCO/WHO/UNEP, 1996). High nitrate levels $(>1 \mathrm{mg} / \mathrm{l})$ are not good for aquatic life (Johnson et al., 2000). This could be the reason why all the fish fauna indicated positive correlation to other physicochemical parameters with only negative correlation to Total dissolved solids, Conductivity, Calcium, $\mathrm{pH}$ and Alkalinity. The high level of nitrate observed is in line with the findings of Wolfhard and Reinhard (1998), who concluded that nitrate are usually built up during dry seasons and that high levels of nitrates are only observed during early rainy season which correspond to the period of the research work. This also played a vital role in the abundance of both fish and phytoplankton. Tilapia zilli like other fishes appears to be sensitive indicator of changes as they have a temperature tolerance range of $25^{\circ} \mathrm{C}$ to $30^{\circ} \mathrm{C}$ with less alkalinity of 16 to $20 \mathrm{ppt}$ compared to ammonia in their natural waters. Clarias gariepinus have possessed an ability to tolerate adverse water quality and difficulty in aquaculture. Lates niloticus are found to be less abundant in oxygen poor condition in water quality. The positive correlation of most fishes like cladocerans with dissolved oxygen and biochemical oxygen demand was an indication the reservoir was unpolluted; Balogun et al. (2005) in Makwaye (Ahmadu Bello University Farm) made similar observation. Fish and phytoplankton in Gwaigwaye reservoir, also indicated monthly variation in abundance that may be due to variations of physicochemical parameters. Food condition is still considered an important factor affecting growth and reproduction of zooplankton including fish fauna in nature, especially in closed environment such as reservoirs and lakes (Mahar, 2003).

Table 1: Monthly Fish Landing in Gwaigwaye Reservoir

\begin{tabular}{|c|c|c|c|c|c|c|c|c|c|c|c|c|c|}
\hline Fish Fauna Species & ne $(96)$ & ly $(\%)$ & $\begin{array}{l}\text { August } \\
\left(\mathrm{O}_{0}\right)\end{array}$ & $\begin{array}{l}\text { September } \\
(\%)\end{array}$ & $\begin{array}{l}\text { October } \\
(\%)\end{array}$ & & & & & $\begin{array}{l}\text { March } \\
(\%) \text {. }\end{array}$ & April (96) & $\operatorname{May}(90)$ & Total $(96)$ \\
\hline $\begin{array}{l}\text { yad } \\
\text { II } \\
\text { uriepinus }\end{array}$ & & & & & & & & & & & & & \\
\hline & & & $17(9 / 71)$ & $18(10.06)$ & $12(11.43)$ & 1.91700 & $10(11.49)$ & $8(6.56)$ & 82) & $7(6.25)$ & & & \\
\hline $\begin{array}{l}\text { Treochromis niloticus } \\
\text { ynodontis clariøs } \\
\text { abeo senegalensis } \\
\text { ates niloticus } \\
\text { lonthly Total }\end{array}$ & $\begin{array}{l}6.85) \\
70) \\
98) \\
61) \\
11.76)\end{array}$ & $\begin{array}{l}17(9.88) \\
11(6.40) \\
10(5.81) \\
15(8.72) \\
172(10.99)\end{array}$ & $\begin{array}{l}27(15.43 \\
14(8.00) \\
10(5.71) \\
18(10 / 29 \\
175(11.1\end{array}$ & $\begin{array}{l}22(1 \\
9(5 . \\
12(6 \\
250\end{array}$ & $\begin{array}{l}17(16.19) \\
4(3.81) \\
13(12.38) \\
20(19.05) \\
105(6.71)\end{array}$ & $\begin{array}{l}15(15.96) \\
5(5.32) \\
11(11.70) \\
18(19.15) \\
94(6.01)\end{array}$ & 24) & $\begin{array}{l}16(13.11) \\
12(9.84) \\
5(4.10) \\
16(13.11) \\
122(7.80)\end{array}$ & & & & & $\begin{array}{l}\text { 21) } \\
\text { 8) } \\
\text { 1) }\end{array}$ \\
\hline
\end{tabular}

Key: BB - Bagrus bayad, TZ - T. zilli, CG-Clarias gariepinus, MS-Mormyrus senegalensis, ON-Oreochromis niloticus, SC-

Synodontis clarias, LS - Labio sengalensis, LN-Lates niloticus. Note: Means of the same superscript along the columns are not significantly different at $\mathrm{p} \geq 0.05$.

Table 2: Correlation between Fish species and physicochemical parameters of Gwaigwaye reservoir Funtua, Katsina state.

\begin{tabular}{|c|c|c|c|c|c|c|c|c|c|c|c|c|c|c|c|c|c|c|c|c|c|}
\hline 7 & $B B$ & $T Z$ & $C G$ & $M S$ & $O N$ & $S C$ & L.S & $L N$ & $D O$ & $\mathrm{Cl}$ & PO4 & $N$ & 504 & $p H$ & Temp & $E C$ & TDS & $H$ & $B O D$ & $\mathrm{Ca}$ & Allk \\
\hline$B B$ & 1.0 & & & & & & & & & & & & & & & & & & & & \\
\hline$T Z$ & $0.6^{*}$ & 1.0 & & & & & & & & & & & & & & & & & & & \\
\hline$C G$ & $0.6^{*}$ & $0.6 *$ & 1.0 & & & & & & & & & & & & & & & & & & \\
\hline$M S^{\circ}$ & $0.6^{*}$ & 0.3 & $0.5^{*}$ & 1.0 & & & & & & & & & & & & & & & & & \\
\hline$O N$ & $0.5^{*}$ & 0.3 & 0.2 & $0.5^{*}$ & 1.0 & & & & & & & & & & & & & & & & \\
\hline$S C$ & $0.5 *$ & $0.6^{*}$ & $0.6 *$ & $0.6^{*}$ & $0.7^{*}$ & 1.0 & & & & & & & & & & & & & & & \\
\hline LS & 0.2 & 0.0 & 0.0 & 0.3 & -0.2 & -0.3 & 1.0 & & & & & & & & & & & & & & \\
\hline$L N$ & -0.1 & 0.2 & -0.2 & -0.1 & -0.3 & -0.4 & $0.7^{*}$ & 1.0 & & & & & & & & & & & & & \\
\hline DO & 0.1 & 0.2 & 0.3 & 0.1 & 0.2 & $0.5^{*}$ & 0.0 & -0.1 & 1.0 & & & & & & & & & & & & \\
\hline $\mathrm{Cl}$ & $0.7^{*}$ & 0.4 & $0.6^{*}$ & $0.7^{*}$ & 0.3 & 0.3 & $0.5^{*}$ & 0.0 & 0.1 & 1.0 & & & & & & & & & & & \\
\hline $\mathrm{PO}_{4}$ & 0.3 & 0.3 & 0.1 & 0.1 & 0.2 & 0.2 & 0.4 & $0.5^{*}$ & $0.6^{*}$ & 0.2 & 1.0 & & & & & & & & & & \\
\hline $\mathrm{N}$ & $0.5^{*}$ & 0.3 & $0.5^{*}$ & 0.3 & 0.2 & 0.2 & 0.2 & 0.0 & 0.5 & $0.6^{*}$ & $0.6^{*}$ & 1.0 & & & & & & & & & \\
\hline SO4 & $0.6^{*}$ & $0.5^{*}$ & 0.4 & $0.5^{*}$ & 0.2 & 0.1 & $0.7^{*}$ & 0.4 & 0.1 & $0.9^{*}$ & 0.4 & $0.5^{*}$ & 1.0 & & & & & & & & \\
\hline $\mathrm{pH}$ & -0.1 & -0.2 & -0.3 & 0.0 & 0.0 & $-0.6^{*}$ & 0.3 & 0.4 & $-0.7 *$ & 0.2 & -0.2 & -0.2 & 0.3 & 1.0 & & & & & & & \\
\hline Temp. & 0.4 & 0.3 & 0.0 & 0.4 & 0.0 & 0.1 & 0.2 & -0.1 & $-0.5 *$ & 0.4 & -0.3 & 0.1 & 0.3 & 0.1 & 1.0 & & & & & & \\
\hline EC & -0.3 & -0.4 & -0.3 & -0.4 & 0.2 & 0.0 & -0.4 & -0.1 & 0.2 & $-0.7 *$ & 0.2 & -0.4 & $-0.6^{*}$ & -0.1 & $-0.8^{*}$ & 1.0 & & & & & \\
\hline TDS & -0.1 & $-0.6^{*}$ & -0.3 & -0.2 & 0.1 & -0.3 & -0.1 & -0.3 & -0.1 & 0.0 & 0.0 & 0.1 & -0.1 & 0.2 & -0.1 & 0.3 & 1.0 & & & & \\
\hline & $0.6^{*}$ & 0.3 & $0.5^{*}$ & $0.5^{*}$ & 0.3 & 0.1 & 0.3 & 0.1 & -0.1 & $0.8 *$ & 0.3 & $0.8 *$ & $0.7^{*}$ & 0.3 & 0.4 & $-0.5^{*}$ & 0.1 & 1.0 & & & \\
\hline BOD & 0.1 & 0.1 & 0.3 & -0.1 & -0.2 & 0.1 & 0.0 & -0.4 & 0.4 & 0.3 & 0.0 & 0.3 & 0.1 & $-0.5^{*}$ & 0.1 & -0.3 & 0.1 & -0.1 & 1.0 & & \\
\hline $\mathrm{Ca}$ & 0.1 & 0.2 & 0.3 & 0.0 & 0.4 & 0.2 & -0.1 & 0.0 & $0.6^{*}$ & 0.3 & $0.5^{*}$ & $0.6^{*}$ & 0.4 & 0.0 & $-0.5 *$ & 0.2 & 0.2 & 0.4 & 0.1 & 1.0 & \\
\hline Alk & 0.3 & 0.0 & 0.2 & 0.4 & 0.1 & -0.2 & $0.5^{*}$ & 0.1 & -0.3 & $0.8^{*}$ & -0.1 & 0.4 & $0.8^{*}$ & $0.6^{*}$ & 0.4 & $-0.6^{*}$ & 0.3 & $0.7^{*}$ & 0.2 & 0.2 & 1.0 \\
\hline
\end{tabular}

Key BB-Bagrus bayad, TZ - T. zilli, CG-Clarias gariepinus, MS-Mormyrus senegalensis, ON-Oreochromis niloticus, SCSynodontis clarias, LS - Labio sengalensis, LN-Lates niloticus, DO-Dissolved Oxygen, Cl-Chloride, PO4 - Phosphate, N-Nitrates, SO4, - Sulphate, $\mathrm{pH}-\mathrm{pH}$ value, Temp. - Temperature, EC-Electrical Conductivity, TDS - Total Dissolved Solids, H-Hardness, BOD Biological Oxygen Demand, Ca-Calcium, Alk-Alkalinity. 
Conclusion: The fish faunas were Bagrus bayad had a toal mean and percentage of: 202 (12.91), Tilapia zilli 271 (17.32), Clarias gariepinus: 253 (16.17), Mormyrus senegalensis: 155 (9.90), Oreochromis niloticus: 238 (15.21), Synodontis clarias: 114 (7.28), Labeo senegalensis: 116 (7.41) and Lates niloticus: 216 (13.80). All the fish fauna composition and abundance were increased during rainy season and decreased with dry season. The fish species analyzed in this study showed correlation with the physicchemical parameters which indicates a relationship between them.

\section{REFERENCES}

Adeyemi, SO; Akombo, PM; Toluhi, OO (2009). Food and feeding habit of Oreochromis niloticus in lake Gbedikere,Bassa, kogi state. Cont. J. Animal. Vet. Res. 1:25-30.

Aparicio, E; Vargas, M; Olmo, J; desostoa, A (2000). Decline of native freshwater fishes in a Mediterranean watershed on the Iberian Peninsula: a quantitative assessment. Environ. Biol. Fishes, 59: 11-19.

Balogun, JK (2006). Basic fisheries Biology and Management for tertiary institution. Ayo-sule printers zaria, Nigeria. 10-30pp.

Babatunde, DO; Raji, A (2004). Field guide to Nigeria freshwater fishes. Federal College of Freshwater Fisheries Technology. New Bussa Nigeria. 104pp.

Dudgeon, D; Arthington, AH; Gessner, MO; Kawabata, ZI; Knowler, DJ (2006). Freshwater biodiversity: importance, threats, status and conservation challenges. Biol. Rev. 81: 163-182.

Edward, JB; Ugwumba, AA (2010). Physico-Chemical Parameters and Plankton Community of Egbe Reservoir, Ekiti State, Nigeria Res. J Biol. Sci. 5 (5): 356-367. 100.

Geist, J (2011). Integrative freshwater ecology and biodiversity conservation. Ecological Indicators, 11: 1507-1516.

Helfman, GS (2007). Fish conservation. Covelo, CA: Island Press.10-30pp.

Idodo-Umeh, G (2003). Fresh water fisheries of Nigerian (taxanomy,ecological notes,diets and utilization). Idodo-umeh Publishers. 20-82pp.

F.A.O, (2008). Yearbooks of fisheries statistics. Summary tables. Food and Agriculture Organization of the United Nations. Fisheries and Aquaculture Department. Rome, Italy. 2-10pp.
F.A.O, (2009). The State of World Fisheries and Aquaculture.FAO

Website.www.fao.orglsoflsofialindex_en.htm.

Mahar, MA (2003). Ecology and Taxonomy of Plankton of Manchhar Lake (Distt. Dadu), Sindh, Pakistan.Unpublished PhD. Thesis University of Sindh, Pakistan. Retrieved from: http://usindh.edu.pk.mukhatiar.ahmad/Dessertation _mukhatiar.

Moyle, PB; Katz, JVE; Quinones, RM (2011). Rapid decline of California's native inland fishes: a status assessment. Bio. Conserve. 144: 2414-2423.

Moyle, PB; Kiernan, JD; Crain, PK; Quinones, RM (2012). Projected effects of future climates on freshwater fishes of California. California Energy Commission, Public Interest Research Program. Publication number: CEC-500-2012- 028.

Mustapha, MK (2011). Perspectives in the Limnology of Shallow Tropical African Reservoirs in Relation to Their Fish and Fisheries. J. Transdisciplinary Environ. Stud. 10(1):16-23.

Offem, BO; Ikpi, GU (2011). Water Quality and Environmental Impact Assessment of a Tropical Waterfall System, Environment and Natural Resources Research 11(1). Retrieved from www.ccsenet.org/enrr on 02/01/2012.

Olele, NF; Ekelemu, JK (2008). Physicochemical and Phytoplankton Study of Onah Lake, Asaba, Nigeria. Afr. J. General Agric. 4(3).25

Pauly, G; Leveque, C; Teugels, GG (2004). Fresh water and brackish water fish of West Africa. Publication scientifique du museum, MRAC.IRD Edition. pp 1025.

UNESCO/WHO/UNEP (1996). Water Quality Management Principles. WHO/UNESCO/ E and F Spon, Geneva, Switzerland. Pp 609.

Watson, I (2000). The role of the ornamental fish industry in poverty alleviation. NRI Report 2504. Natural Resources Institute, Ghatham Maritime, Kent, UK. Worldfish Center. 2002. Fish: An Issue for Everyone. A Concept Paper for Fish for All.

Wolfhard, S; Reinhardt, B (1998). The heterogeneity of runoff and its significance for Water quality problems, Hydrobiol. Sci. J. Des Sci. Hydrologiques, 43:103-113. 